\title{
The Treatment Action Campaign's Quest for Equality in HIV and Health: Learning from and Lessons for the Trade Union Movement
}

\author{
Mark Heywood, Section 27, South Africa
}

\begin{abstract}
The Treatment Action Campaign (TAC) has been recognised as one of the most effective social movements in post-apartheid South Africa. Among other things, it is responsible for the world's largest programme to provide anti-retroviral treatment to people with HIV through the public health system. This article looks at the lessons TAC learned from the trade union movement as it sought to build a mass movement of the poor around the human right to access essential medicines for millions of people infected with HIV. It explores how TAC sought to build an alliance with the Congress of South African Trade Unions (COSATU) and its affiliates, and the vital role that an independent COSATU played in supporting AIDS activism and using its social weight to support campaigns for AIDS treatment. Finally it looks at what trade unions can learn from social movements and explains why an effective alliance between unions and social movements is so essential for pro-poor reform in the twenty-first century.
\end{abstract}

\section{Introduction: Birth of a Movement}

On 10 December 1998 a group of ten people gathered on the steps of St George's Cathedral in Cape Town to hold a demonstration to demand access to anti-retroviral treatment (ARVs) for people with the Human Immunodeficiency Virus (HIV). They carried placards asserting that access to life-saving medicine was part of the human right to health. At that point deaths due to infection with HIV were rising rapidly in South Africa yet no people were receiving ARVs, the medicines that were known to treat HIV.

Fifteen years later, according to Dr Aaron Motsoaledi (2014), the Minister of Health, two and a half million people in South Africa were receiving ARV treatment, paid for by the state through the public health system. This was one-third of the global total! Ten years after the ARV treatment programme started in 2004, people's access to treatment has caused the national life expectancy to rise from 50 to 60 years (Malan, 2014). There has also been a dramatic reduction in infant mortality, and by 2011 the rate of vertical HIV transmission from pregnant mothers to their newborns was down to less than $3 \%$ from over $25 \%$ in $1999 .^{2}$

The social movement largely responsible for the introduction of this massive treatment programme in the public health system is called the Treatment Action Campaign (TAC). The TAC, which was nominated for a Nobel Prize in 2003, has grown into a much-studied and globally respected political movement for health. ${ }^{3}$ However, what is not widely appreciated is the relationship that the TAC deliberately built from the outset with the labour movement in South Africa, especially with the Congress of South African Trade Unions (COSATU) and several key affiliates including the National Union of Mineworkers (NUM) and the South African Democratic Teachers Union 
(SADTU).

This article, written by one of the founders of the TAC, aims to record some of that history, and sets out how and why the TAC gravitated to the labour movement, what it learned from labour struggles, how it built on these struggles, and what they suggest for the future about alliances to achieve social justice between the organised working class and social movements of the economically disenfranchised.

\section{Part I}

\section{The TAC's Struggle against HIV and AIDS}

\section{The role of the trade unions in the rise of the TAC}

The TAC was launched in late1998, four years after the advent of democracy in South Africa in 1994. This was at a time when pro-poor movements were tentatively trying to develop strategies suitable to the new political context.

The group of people who came together to found the TAC had already worked together for over a decade in the anti-apartheid struggle. It included leaders such as Zackie Achmat, Laddie and Deena Bosch, Jack Lewis and myself. These were political activists whose experience straddled the apartheid and post-apartheid periods. They had witnessed the vital role that COSATU had played in the overthrow of apartheid. Through massive strikes and stay-aways during the 1980s and early 1990s, the trade union movement had become the backbone of the internal revolt, making the country ungovernable by the National Party and increasingly unprofitable and insecure for the big bosses who had backed the regime.

TAC leaders felt that trade unions would have an equally important role to play in the post1994 transformation of South Africa. A liberation movement, the African National Congress (ANC), was now in power with a radical programme for reconstruction and development. But, based on a study of history, many activists suspected that people's expectations of radical social transformation would not be met, and sought ways to keep communities mobilised to ensure accountability by the new government. A great deal of the power that had brought down apartheid had been dissipated into Parliament and the public services. The trade unions were also weakened as many of their leaders also went into government. There were few models to emulate.

In 1990 COSATU had agreed to join an alliance with the ANC and the South African Communist Party (SACP). According to Jay Naidoo, COSATU's first General Secretary:

COSATU was the biggest organisation in civil society, and we felt very strongly that the ANC, the political movement that was marching in victoriously, should be accountable and should sign a reconstruction pact. COSATU was always clear that it could never be a 'rubber stamp' for any political party (Naidoo, 2010: 186).

Zwelinzima Vavi (2014), the third General Secretary of COSATU, has written of how the SACP began almost immediately to seek to blunt workers' struggles and political independence. Nonetheless, COSATU retained a degree of political independence; its affiliates remained one of the few cohesive centres of organised poor people's power. Unlike the ANC, whose members and leaders proved afraid to criticise the President and ANC party line, COSATU showed a willingness to speak out, particularly on AIDS and the desire to remain faithful to the interests of the poor.

In 1994 COSATU already had over a million members. It was therefore the largest, most 
cohesive social movement of working-class and poor people in South Africa, whose involvement in campaigns for HIV prevention and treatment was essential if the TAC was to fulfil its mission of ensuring equal access to treatment for all people with AIDS.

AIDS is also a working-class issue. At one point there was a slogan that 'AIDS doesn't discriminate', a message that was meant to alert people to the fact that it is types of sexual behaviour that place a person at risk rather than types of people. In reality, however, the transmission of HIV is intricately connected to poverty and inequality. This means that AIDS is a political issue, and an alliance with the trade unions was a natural one.

What do we mean by this?

HIV was first detected in South Africa in the mid-1980s but went relatively unnoticed and unchecked during the following decade. In the early 1990s several organisations and political leaders attempted to alert South Africans to the potential threat posed by HIV. This included Chris Hani, the leader of the SACP who was assassinated in 1993. In 1990 Hani warned that 'we cannot afford to allow the AIDS epidemic to ruin the realisation of our dreams'. Unfortunately Hani and others were largely unheard or disbelieved.

The rapid spread of HIV was tied to the structure of the labour market upon which apartheid and capitalist industry, the mines in particular, had depended. In the late 1980s HIV was first detected among migrant mineworkers coming from East African countries, Malawi in particular, which had been close to the epicentre of the African AIDS epidemic in the 1980s. Once HIV infection took hold in South African mining communities, it found ready-made paths for further transmission, paths that had already been laid by the mining industry. For example, the pre-existing epidemics of diseases such as syphilis and gonorrhoea created higher risks of being infected with HIV. Once HIV had become epidemic among mine workers it added to pre-existing mortality caused by tuberculosis and silicosis - both already epidemics in the mines (Jochelson, Mothibeli and Leger, 1991: 21, 157-173).

In the context of migrant labour and high unemployment, sex work has always been a factor in the spread of HIV, with very high rates of infection documented among male and female sex workers (Chiumia, 2015). Similarly, the very high rates of HIV infection that are seen in girls and women are explained by patriarchy, gender inequality and violence against women - something trade unions have been unwilling to confront. Indeed, even something as basic as lack of access to quality education has been shown by researchers to be a factor linked to a higher vulnerability to HIV.

Finally, by the 1990s there was a growing epidemic of unfair discrimination against workers with HIV. This surfaced in the late 1980s initially through attempts by mine bosses to introduce mandatory HIV testing, to refuse employment to workers with HIV, and to dismiss those that they found to be HIV-positive. ${ }^{4}$

The connections between AIDS, inequality and politics should have made HIV prevention an obvious issue for trade unions to take up in the 1990s, but they were slow to do so. It was in this context that the TAC and other AIDS activist organisations such as the AIDS Consortium and AIDS Law Project (ALP) considered it vital that members of the organised trade union movement were given access to information and education about the risk that HIV posed to the lives and health of workers and their families.

\section{Building trust: the role of trade unions in the TAC's campaign against profiteering from medicines}

During the 1990s HIV rapidly assumed pandemic proportions in South Africa (Gouws and Karim, 2005). But the 1990s were also a time of fierce political struggle and, after 1994, the 
beginnings of profound political transformation. In this context the threat posed by HIV was not prioritised and, because of stigma, rarely spoken of openly (Heywood, 2005b, 2010).

By the time the TAC launched its campaign for treatment in 1998, AIDS was becoming more visible and more difficult to hide. There was a growing stigma around the few people known or thought to have HIV and a rapid rise in deaths caused by AIDS (Dorrington and Bradshaw, 2005). Unfortunately, through a combination of stigma, fear and denial, the steady rise in adult mortality was often attributed to other causes. ${ }^{5}$

As I have already explained, the epidemiology of HIV mirrored social fault lines created by the apartheid migrant labour system. Its spread was initially heavily influenced by the structure of the apartheid labour market, explaining the high rates of HIV infection seen among mine workers. The same explanation could be applied to those who died of AIDS, most of whom were black and poor.

However, by the early 1990s rapid advances in scientific and medical understanding had led to the development of a new generation of medicines known as anti-retrovirals. In developed countries these medicines had begun to turn HIV into a chronic but no longer fatal disease - if you could afford the medicines. The vast majority of people could not.

When the TAC was founded in late 1998, our primary aim was therefore to make access to ARVs possible for poor people. The TAC argued that because 'health for all' by 2000 was the aim of the United Nations 1970 Alma Atta Declaration and because more and more constitutions (including South Africa's) regarded health as a human right, people in developing countries were equally entitled to have access to ARVs. The TAC therefore planned campaigns that would target multinational pharmaceutical companies and force them to reduce the price of ARVs. We had a model of sorts. Activist campaigns for access to treatment had started in the United States (US) in the 1980s and 1990s, primarily among gay, white, middle-class men. ${ }^{6}$ We were inspired by and learned from these campaigns, but had to replicate them in a very different social environment. The TAC's 'constituency' was 'straighter' and poorer, less educated and less empowered. While white, professional gay men had played a crucial role in starting the AIDS movement in South Africa, the TAC's objective was to build a movement that was primarily black, poor, female and led by people living with HIV. By doing so we would be shifting the centre of gravity of the activist response from where it had originated in the United States to the new epicentre of the HIV epidemic: Africa and the developing world.

The TAC needed to become a mass movement, not least because this would be the only way to mobilise the communities most affected by HIV. To begin with, however, it had to look for sources of power, allies who could help mobilise a new movement of the hitherto unorganised. For this reason, very soon after it was founded the TAC began working to build a relationship with the trade union movement. It was aided by the fact that the AIDS Law Project, one of the organisations instrumental in establishing the TAC, had already built a relationship with the NUM and several other COSATU affiliates through its efforts to outlaw HIV-related unfair discrimination at work, especially pre-employment HIV testing. To counter this discrimination the ALP had pioneered a proposal for a legally binding HIV/AIDS and Employment Code of Good Conduct, and successfully sought the support of trade unions for this (Moyle, 2015).

From early 1999 the TAC sought meetings with individual trade union leaders. After its first national congress in 2000 was addressed by Willie Madisha, then the President of COSATU, the TAC established a National Council which included a labour sector, with a space reserved on it for COSATU. In addition, it began a patient on-going process of education and engagement with trade unions about the medical, political and social dimensions of the HIV epidemic that continues to this day. Over time the TAC and the ALP became the de facto advisers to the unions on issues related to 
HIV and spoke on several occasions at the COSATU Central Executive Committee on the issue of HIV.

However, the first campaign where TAC was really able to catalyse involvement and support from the trade unions was in a campaign over the South African government's right to pass a law that aimed to curtail the power of pharmaceutical companies and improve the affordability of medicines.

In 1997 one of the early progressive legislative acts of the new democratic government had been to amend a law regulating medicines. The aim was to weaken the stranglehold of pharmaceutical companies that, through the abuse of the patent system, kept the price of medicines extremely high and unaffordable for a developing country government. In order to do this President Nelson Mandela's government amended the Medicines and Related Substances Act in 1997. This immediately drew the ire of the pharmaceutical industry which, under the auspices of an industry body known as the Pharmaceutical Manufacturers' Association (PMA), ganged together and launched litigation to stop the new law being implemented. From its side the US government, a faithful ally of big pharma, placed South Africa on a trade 'Watch List' and began to exert substantial behind-the-scenes political pressure on the government not to implement the Act. Heightened protection of intellectual property was one of the hallmarks of the neo-liberal world order, symbolised by the formation of the World Trade Organisation (WTO) and its 1995 Agreement on Trade Related Aspects of Intellectual Property (TRIPS). But ironically the dispute between the United States and South Africa over intellectual property in medicine offered the bridge that made it possible for AIDS activism to cross the Atlantic and take root in the developing world.

The fight over patent protection was also indicative of the growing globalisation of social issues and of the potential for North-South solidarity on issues of human rights and equality. In 2000 activists in the United States launched a campaign to force the Clinton administration to back off from South Africa. At the head of its campaign were people living with HIV from the AIDS Coalition to Unleash Power (ACT-UP) in New York. They had experience of campaigning for medicines to save their own lives, but now turned to show solidarity with activists in developing countries. The target of their campaign was Presidential candidate Al Gore, who chaired the USSouth Africa Bilateral National Trade Commission which was putting pressure on South Africa to rescind its law.

ACT-UP's work challenging patents and prices had commenced before the TAC was formed, but the TAC's birth in the late 1990s had created an organisation that could pick up this campaign on the other side of the Atlantic. The TAC was also able to use the evidence and arguments drawn up in the US-initiated campaign to help its own mobilisation and draw attention to its own demands for access to medicines for people with HIV.

When the TAC decided to join the court case brought by the PMA on the side of the South African government, COSATU was drawn into the campaign from the beginning. In an article titled Debunking Conglomo-talk, I describe how COSATU's campaigns organiser, Theodora Steele, became the deponent to the Founding Affidavit challenging the pharmaceutical companies, and how on the eve of the court hearing the TAC and COSATU staged an all-night vigil in a tent outside the court. The article records that 'TAC leaders seized the rare opportunity to workshop the most senior officials of COSATU until two in the morning on legal and political issues posed by the case' (Heywood, 2002a: 143). The next day, then COSATU General Secretary Zwelinzima Vavi joined a 5000 -strong march organised by the TAC to protest at the United States Embassy as well as outside the Pretoria High Court.

The PMA campaign marked the arrival of the TAC as a new social movement, and COSATU

Global Labour Journal, 2015, 6(3), Page 318 
and the trade unions had become a central part of this campaign. The TAC-COSATU alliance forced pharmaceutical companies onto the back foot. Huge publicity surrounded the case, and the campaign made access to medicines for poor people, and the duties and powers of states arising from the recognition of the right to health, one of the twenty-first century's great politico-moral issues.

An intense political focus developed around the abuse of patents for profiteering and the manner in which the WTO TRIPS Agreement elevated intellectual property rights above the interests of public health. ${ }^{7}$ Extensive international solidarity and publicity created an environment in which the pharmaceutical companies could not sustain their attack. ${ }^{8}$ After a ruling by the judge that the TAC and COSATU would be allowed to join the case as amici curiae (friends of the court) in April 2001, the PMA withdrew from the case, leaving the South African government free to implement the law.

In the years after the PMA case, the TAC cemented its relationship with trade unions with further joint campaigns against profiteering from medicine. For example, in late 2002 the TAC, together with COSATU and the Chemical Engineering Paper Wood and Allied Workers Union (CEPWAWU) filed a detailed complaint at South Africa's Competition Commission alleging patent abuse by two multinational companies, GlaxoSmithKlein and BoehringerIngelheim. A year later the settlement in this case broke the monopolies of the two companies on three essential ARVs (AZT, 3TC and Nevirapine) leading to dramatic price reductions that for the first time made the medicines affordable for the public health sector (Competition Commission, 2014: 13-15).

\section{Testing trade union independence: the fight against AIDS denialism}

In some ways an alliance between the TAC and the trade unions to fight profiteering and private power was easy. Fighting private power kept the trade unions in their comfort zone. Unlike the next battle over AIDS policy, which would be with the ANC and the government, it was relatively uncontroversial. It did not require independent political choices to be made.

When it was launched the TAC had envisaged that if it was successful in forcing pharmaceutical companies to drop ARV prices this would open the door for government health programmes that would provide access to medicines to people with HIV, starting with relatively inexpensive ARVs that had been proven to reduce the risk of mother to child transmission (MTCT) of HIV. The TAC saw the ANC government as its ally, requiring only persuasion and education to implement HIV treatment programmes.

The TAC had not anticipated what became known as 'AIDS denialism' or that the ANC government under then President Thabo Mbeki (1999-2008) rather than the multinational pharmaceutical companies would prove to be the main barrier to treatment for people with HIV.

The history of AIDS denialism in South Africa is a complex one. The term refers to a period when the ANC under the leadership of Mbeki questioned whether HIV really existed, sometimes argued that HIV was an 'imperialist invention' and claimed that poverty rather than HIV was the cause of AIDS (suggesting at one point that this was just a 'thesis').

As the government got sucked deeper into the embrace of AIDS denialism, it also began to virulently oppose the TAC's demand that they implement a programme to prevent mother to child HIV transmission. This was on the grounds that ARVs were highly 'toxic' and that they were the real cause of AIDS. ' The advent of AIDS denialism forced the TAC into a six-year period of fierce confrontation with the ANC and the government - one which the TAC eventually won.

The TAC's conflict with the government was the first time after the end of apartheid that civil society came into conflict with the ANC. The TAC was a new, relatively unknown organisation, and

Global Labour Journal, 2015, 6(3), Page 319 
attempts were made by ANC leaders to stigmatise it, claiming falsely that it was 'counterrevolutionary' or a 'front' for pharmaceutical companies, and questioning the bona fides of its leaders, alleging for example that white leaders like myself were using black people as cannon fodder and rent-a-crowd.

Efforts were also made to split the alliance that had been built with the trade unions during the PMA case. Unfortunately for the ANC, under the leadership of General Secretary Zwelinzima Vavi and President Willie Madisha (both of whom had been elected at COSATU's $12^{\text {th }}$ Congress in 1999) COSATU withstood one of the first real tests of its independence and ability to challenge the ANC in government. For example, in reaction to allegations that COSATU had been 'infiltrated' by the TAC, the newspaper of the South African Democratic Teachers Union (SADTU) led with a headline that cried out, 'No, Mr President, we cannot infiltrate ourselves'.

However, maintaining an alliance with COSATU during this period was not easy. To counter misinformation about the TAC as well as AIDS denialist propaganda, it became necessary to intensify worker and leader education about HIV. In 2002, for example, the TAC produced a booklet on Questions and Answers About TAC for COSATU shop stewards. The TAC also had to continually and carefully explain strategies and tactics that were unfamiliar to the unions, particularly why turning to the courts to resolve disputes was neither anti-ANC nor anti-government but an assertion of rights and democracy that now existed under the Constitution.

Working more behind the scenes than in the open, the TAC continued to foster its alliance. Notably, in 2002 the TAC had started to call for a National ARV Treatment Plan. In tandem with the labour representative at South Africa's National Economic Development and Labour Council (NEDLAC), it tabled proposals for a treatment plan. This was done in close collaboration with Ebrahim Patel, the labour sector's negotiations leader at NEDLAC and general secretary of the South African Clothing and Textile Workers Union (SACTWU). The TAC won the support of both labour and business for a treatment plan, but in late 2002 the government scuppered the negotiations.

As a result, in early 2003 the TAC launched a civil disobedience campaign against the ANC government to enforce its demand for a treatment plan. This started with laying charges of culpable homicide against the Minister of Health and the Minister of Trade and Industry, the latter a former COSATU leader, Alec Erwin. While COSATU criticised this campaign publicly, behind the scenes the TAC had made extensive efforts to explain the campaign to COSATU leaders, and several leaders indicated their understanding and support for why it had become necessary - even though they had to criticise it publicly.

In the war over AIDS denialism the support of and engagement with older established movements such as COSATU proved vital. The TAC's association with COSATU meant it benefitted from the trust COSATU had already established with the population, while the TAC built up its own public credentials and trust. The symbolic power of the public seeing COSATU leaders speaking at events such as the joint TAC-COSATU National Treatment Congress in 2002 cannot be underestimated. ${ }^{10}$

In this there is perhaps a lesson for trade unions the world over. Many trade unions have a history and social legitimacy that is not the case with the new social movements. In struggles for social justice, the trade unions also have a unique historical memory, tradition, experience and stability. Because of this, they have an important role to play in mentoring and supporting progressive social movements. The relationship built between the TAC and COSATU is proof of this. In the era of neo-liberalism the political and workplace power of trade unions may have been whittled down by mass unemployment and new technologies. Developing alliances and campaigns

Global Labour Journal, 2015, 6(3), Page 320 
in conjunction with social movements is one way to counter this.

\section{Part II \\ Continuity and Innovation: Old and New Strategies for Building People's Power}

The TAC was started by a small group of political activists. Within the founding group only ZackieAchmat was living with HIV, and a minority were women and black. But our aim was to build a mass movement of poor and working-class people, dominated and led by people living openly with HIV and by women. However, then as now, HIV was heavily stigmatised. In 1998 less than ten people out of the estimated two million people infected were open about having HIV.

To try to overcome these challenges, the TAC combined both the old and proven methods of the struggle, learned particularly from the United Democratic Front (UDF) and COSATU, with novel and pioneering strategies, some of them imported from the struggle for AIDS treatment in the United States. The old methods included popular education and mobilisation. The new method was to combine this with human rights advocacy and, where necessary, with social justice litigation, now made possible by South Africa's progressive pro-poor Constitution. The TAC's formula for building people's power might be described as follows:

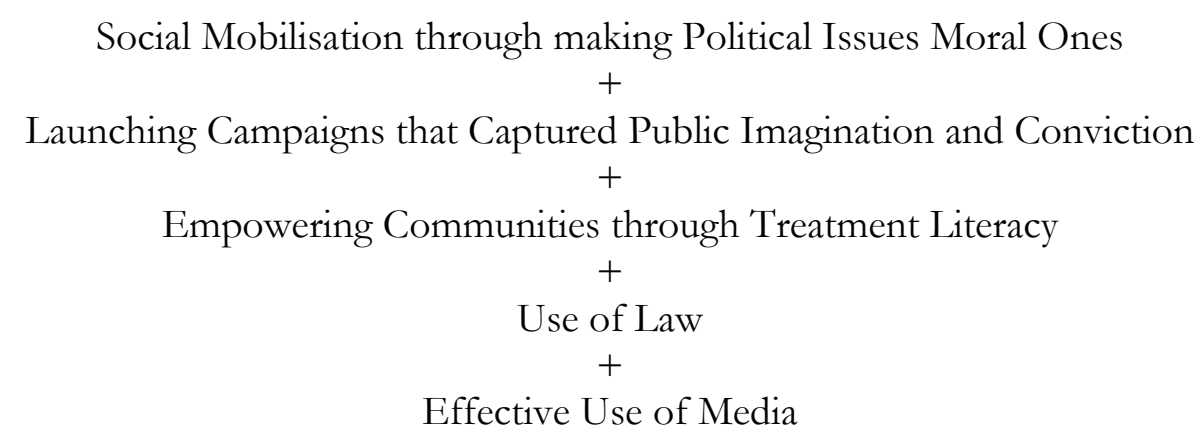

In the TAC's campaigns, all the parts of this formula were usually implemented in combination. However, below I shall say a little about the various elements that made up the campaigns.

\section{Creating identity}

The TAC's first challenge was to create an identity. Creating greater openness about HIV was intricately linked to establishing the TAC's identity. If more people with HIV were open about it, then it would be possible create faces for the pain, indignity and illness suffered as a result of being denied access to ARVs.

T-shirts have been used to carry the messages of political trade union campaigns for decades. The TAC bought into this tradition. As part of its public campaign to demand the drug AZT for pregnant women with HIV, which took place from January to March 1999, culminating on Human Rights Day (March 20), TAC members wore T-shirts that on the front simply stated 'HIV positive', in a box in which 'HIV' appeared in bold and placed above the word 'positive'. On the back was a political message or campaign slogan, one which has changed many times over the years to reflect different campaigns, conferences and activities (Section 27 and TAC, Undated).

The TAC T-shirt was unusual for political T-shirts because it evoked a strong response in both the person who wore it and the person who noticed it. For the former, it meant assuming the 
mantle of a highly stigmatised illness that most people did not admit to or talk about. On the other hand, people observing the T-shirt frequently had to check their own reactions, making them aware of their own prejudices and contribution to the stigma surrounding HIV. 'Does this person really have HIV? Can I sit next to her, drink with him, associate with them?' In the early days of the AIDS epidemic these really were the questions and the responses it elicited. This way an HIV-negative person could feel directly the stigma associated with HIV. For an HIV-positive person it was a way of turning the mark of stigma into the trademark of struggle. Over time the 'HIV Positive T-shirt' grew to be a global brand and has been replicated by AIDS activists in all corners of the world.

\section{Tooling up: building treatment literacy among the poor}

While the TAC can be said to have pioneered certain methods, it looked to history for others. In South Africa, as elsewhere, the trade union movement was built through shop steward training and education in politics, law and methods of organising (Naidoo, 2010: 50-51).The TAC emulated the union movement when it instituted a programme for HIV treatment literacy and extended this to education on law and politics.

The first leaders of the TAC understood that HIV was a complex virus and that building power depended on defeating myths, fears and superstition, as well as equipping activists to be their own advocates. To this end, the TAC's leaders looked to the example of ACT-UP in the United States, an organisation that had pioneered activist knowledge of their own health and scientific advocacy for effective treatments. ACT-UP's evidence-based and science-informed approach to advocacy created the pressure on the research community in the United States, as well as on pharmaceutical companies, that led to the rapid development of anti-retroviral treatment. In South Africa we called this 'treatment literacy'.

At the time it was formed, the TAC did not have connections with the scientific and medical community. Neither did any of its leaders have home-grown scientific knowledge of medicine, virology or causes of illness. To rectify this, early in 1999 the TAC established contact with ACT-UP in New York and invited several of their leaders to come to Johannesburg to run an educational workshop for TAC activists.

This workshop heralded the beginning of TAC's treatment literacy programme. TAC leaders began to learn about the virology of HIV, immunology and HIV's impact on the immune system, the process and progress of HIV infection, opportunistic infections and the medicines (past, present and hopefully future) that were available to treat HIV. In the field of medical science this tooling-up is akin to political activists and trade unionists learning about political economy and history, a vital tradition that seeks to give poor people the knowledge they need to become advocates and activists in their own interests. Although this tradition was inherited from the labour movement, there are signs today of reduced attention being given to political education in many unions. Further, in many unions political education has become ossified, dogmatic and heavily ideological, leaving union activists ill-prepared to provide leadership on the day-to-day struggles and emerging issues that face twenty-first century activists. This weakens shop-floor activism, negotiating power and the respect that the unions could command in society more broadly.

Once an initial group of TAC leaders had attained this knowledge, the TAC began to create a programme that carried complex and cutting-edge medical and scientific knowledge out of universities and academic journals and into rural and urban communities of poor people affected by HIV. A formal training programme in treatment literacy was organised, with train-the-trainer, trainer and activist qualifications. In addition, a series of simply written (but not simple or condescending) manuals were written for TAC activists, including a series that set out medical facts in a clear and

Global Labour Journal, 2015, 6(3), Page 322 
easy-to-understand way - HIV in Our Lives, ARV in Our Lives, TB in Our Lives and Organising in Our Lives. ${ }^{11}$ As a result of this programme one of the things that marked TAC activists became their knowledge of medicine and their ability to negotiate on an informed basis with policy makers, researchers and health workers.

Treatment literacy helped the TAC to build its power in numerous ways. It was a bridge to the scientific community whose support for the TAC's advocacy and demands became vital; it won the respect of health workers; and it won the respect of members of the community who could see that TAC activists were knowledgeable and that their demands were underpinned by a thorough knowledge and understanding of HIV. The programme broadened the TAC's leadership and created capacity for engagement on HIV issues at community level in clinics and hospitals. It takes a long time to develop leadership skilled in the art of activism (perhaps up to a decade), but with the emergence of new layers of leaders there are signs that this has been successful.

\section{Poor law: invoking the South African Constitution}

Under colonialism and apartheid the law had been used to suppress all forms of political opposition as well as to disenfranchise black people and steal their land. In his unfinished autobiography, Joe Slovo, a barrister and later a leader of the SACP and ANC, said:

Until the Verwoerds and the Vorsters could no longer tolerate this, the individual trial could still be a battleground on whose terrain small and temporary social victories could be won. But at the end of the day the judicial system played as vital a role in maintaining South Africa's racist equilibrium as any other branch of the state administration (Slovo, 1995: 58).

As a result the ANC largely eschewed the legal system as a means of effecting change. However, in the dying years of apartheid the liberation movement, including the trade unions, found ways to use the law in the interests of the working class and poor, defending and opening up spaces for organisation and for mobilising communities (Thompson, 1988: 335-49).

In democratic countries where there are labour laws and rights to organise, trade unions generally use the courts as a shield, often resorting to the labour courts to challenge unfair dismissals or in the event of industrial disputes or strikes. In contrast, the TAC used the law as a spear, as a way to frame, articulate and publicise its demands.

The TAC has led the way for a new approach to campaigning for social justice which regards the South African Constitution as a game-changer for the poor. This approach has made extensive use of the Bill of Rights in the South African Constitution, the law, the courts and human rights advocacy to build its power. The TAC is aided by the fact that the Constitution is South Africa's supreme law and creates a legal framework that is centred on the state's duties to respect, protect, promote and fulfil human rights (Heywood, 2013a, 2013b, 2015). This includes the right of 'everyone to have access to health care services' and the government's duty to 'progressively realise this right' by taking 'reasonable legislative and other measures within its available resources' (section 27 of the Constitution).

The TAC discovered that couching its demands for treatment as human rights and then locating them in the Constitution added to both its power and the legitimacy of its claims. Claims seem stronger and more just to the poor and marginalised (even more capable of realisation) when they are described as rights. Claims that are said to be legally entrenched rights are more difficult to dismiss by the rich and powerful especially when legal argument, lawyers and a social movement demand them.

Global Labour Journal, 2015, 6(3), Page 323 
An important point to stress (as this is often an argument made against the use of law) is that the TAC did not disempower its members through use of law, or surrender its campaigns to lawyers and legal process. It worked closely with the AIDS Law Project, a specialist legal NGO, and demonstrated that mobilisation and legal action can interrelate and catalyse each other. A political campaign can give rise to a court case; a court case and the unfolding of different stages of the legal process can sustain a series of demonstrations and a rising movement. ${ }^{12}$

The TAC became the first post-apartheid social movement to take full advantage of the democratic legal framework and particularly of the Constitution, and went further than contemporary social movements in combining litigation with social mobilisation, and making legal advocacy and the use of the law courts into an art. Thus, between 2000 and 2007, the TAC drove its demands hand in hand with a series of court battles:

- in 2001 against the forty multinational pharmaceutical companies who had taken the South African government to court over its Medicines Act;

- in 2001 and 2002 against the South African government in what became a famous Constitutional Court case to demand a programme to prevent mother-to-child HIV transmission;

- in 2002-2003 against the pharmaceutical companies GlaxoSmithKline and BoehringerIngelheim, where the TAC instituted a complaint to South Africa's Competition Commission alleging that these companies were abusing their patents and market dominance to set excessive prices for essential ARVs;

- in 2004 against the South African government (again) to demand access to its plan for the roll-out of ARVs;

- in 2006 to demand that the right of access to ARV treatment be extended to prisoners. Although this case was about prisoner's rights, it was also the case that eventually ended the period of AIDS denialism. As a result of the embarrassment this caused at an international AIDS conference, after one of the prisoners died, the government asked for negotiations with the TAC that led to the country's first holistic and ambitious National Strategic Plan (NSP) on HIV covering the years 2007-2011.

In democratic countries where pro-poor laws exist, using legal process and the courts can be a way of building power. It can be a means by which poor people can assert their power over an arm of the state (the judiciary) that is most often used by the rich (but which their taxes also pay for) and make it work in their interests. However, there must be qualifications linked to this approach: it must be accompanied by media, social mobilisation, public education about the legal questions that are being tested, and control by activists of the lawyers they employ and over decisions taken during the legal process.

\section{Building power in the communities}

Political education, treatment literacy and use of law all aimed to catalyse social mobilisation around HIV treatment. The TAC's campaigns were for tangible and understandable demands, and they only ended once a demand had been won. In many struggles, including recent political struggles led by trade unions in South Africa, poor people are mobilised for social demands which are left hanging and then allowed to quietly slip off the political agenda until the next time poor people are called out to demonstrations. In 2008, for example, COSATU 'threatened to bring the country to a standstill over soaring food and petrol prices’ (Thomas, 2008). But the campaign fizzled out without 
explanation after several mass marches and demonstrations. In the meantime hunger and food inflation have grown worse.

Mobilising and demobilising the poor in struggles for human rights encourages cynicism and apathy. It reminds one of the nursery rhyme about the 'grand old Duke of York' who marched his army up to the top of the hill 'and then he marched them down again':

And when they were up, they were up,

And when they were down, they were down,

And when they were only half-way up,

They were neither up nor down.

A better approach is one where each successful struggle raises confidence and builds people's belief in their power and thereby lays a foundation for the next campaign. For example, the19992002 campaign for a public health programme to 'prevent mother-to-child HIV transmission' was successful after the Constitutional Court judgment in July 2002. But this campaign laid the foundation for its succeeding campaign (2002-2004), that all children and adults with HIV receive treatment ('A National Treatment Plan'), and then for the TAC's demand (2005-2006) that this right be extended to marginalised groups, such as prisoners.

These were separate but linked campaigns that saw the steady growth of the size and influence of the movement. At its peak in 2003-2004, the TAC had over 35000 activist members in six of South Africa's nine provinces, organised in hundreds of community branches. Paradoxically, however, with the growth of a social movement comes substantial risks (which I discuss in Part III of this article).

\section{Empowering struggle: winning and holding the moral high ground}

Struggle and social mobilisation is an art. It is a contest for attention and meaning. This is why it is important that imagination and thought are deployed in campaigns and that work is done to develop plausible alternatives to the policy that is being challenged. Effective campaigns should not just be against something, but should seek to convince the public generally about how a demand can be achieved and why it is unjust or immoral to deny it.

For example, the 'official' reasons given to the TAC about why an ARV treatment plan was not possible related to its 'unaffordability'. It was also said that the weak South African public health system could not support a programme of providing millions of people with medicines. The TAC countered this by working with economists and health experts to develop a shadow plan that rallied evidence to dispute these arguments.

It is vital for social movements, including the trade unions, to consider how to win broad public support for a campaign. Campaigns can be drab and exclusive or they can be challenging, thought-provoking and inspirational. At a number of crucial points, the TAC was able to make its political points much stronger through imaginative campaigns that centred on the immorality of profiteering from or withholding life-saving treatment. In 2001, for example, the TAC's campaign to highlight the drug companies' abuse of patents in order to set excessive prices included organising a well-known local actor to illegally import a generic version of a highly expensive patented medicine, Fluconazole, from Thailand where it cost a fraction of the price of Diflucan, its patented equivalent in South Africa. The medicine was not smuggled into South Africa secretly but in the glare of media publicity and with a TAC demonstration organised in the arrivals lounge of Cape Town International airport to greet the actor (Independent Online, 2001). It was accompanied by a 
challenge to the pharmaceutical company, Pfizer, to sue the TAC for patent infringement. They didn't.

Similarly, in early 2003 when the TAC embarked on its 'civil disobedience' campaign, the campaign started on Human Rights Day, a historic and symbolically laden day that commemorates the 1960 Sharpeville massacre, with marches to police stations in Sharpeville, Durban and Cape Town. At the police stations, TAC activists laid charges of culpable homicide against the Minister of Health and the Minister of Trade and Industry, accusing them of being responsible for thousands of deaths by their refusal to implement a treatment plan. Marchers then refused to leave the police stations if the Ministers were not arrested, leading to hundreds of people being arrested in Cape Town and Durban.

Making a legal case about the implications of the failure to treat people, including through formally submitting a docket and charge sheet at police stations, was powerful and emotive political theatre. ${ }^{13}$ The TAC produced a risqué poster for the campaign which carried photographs of the Ministers of Health and Trade and Industry below the word 'Wanted' (Figure 1).

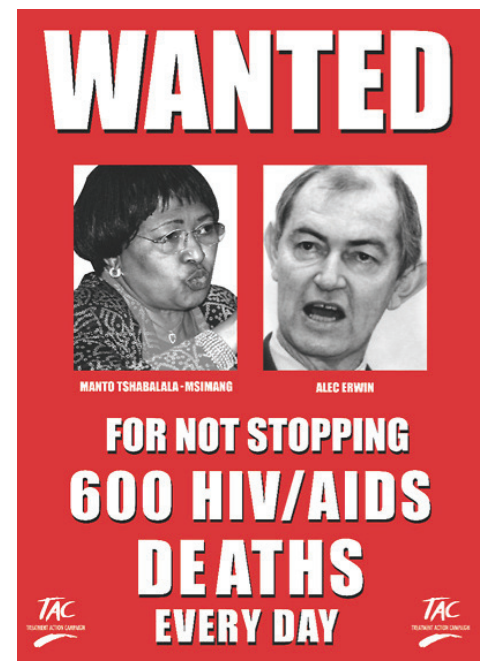

Figure 1: The poster TAC produced for its civil disobedience campaign in 2003

Imaginative campaign methods like this draw a lot from similar strategies used by international NGOs such as Greenpeace, but are relevant for all organisations that campaign for justice, including the trade union movement. Their advantage is that they attract media, garner and deepen public understanding of the issues involved, and win over new supporters. Turning treatment for HIV into a moral question made it possible to win over middle-class people not normally drawn to radical activist campaigns such as breaking patent laws and civil disobedience.

\section{Lessons for the trade union movement}

In the course of these struggles the TAC has learned a number of lessons about organising for social justice. It is worth reflecting on and debating these within the wider justice movement. Perhaps the most important and possibly controversial among radical and socialist movements is the value and potential of building campaigns using legal frameworks, particularly but not exclusively those that have been won by the poor. It may seem to many that decades of struggle by the labour 
movement and organisations of the poor have not succeeded in denting inequality and injustice; unemployment is rising, the casualisation and exploitation of labour is increasing; environmental degradation is more and more apparent; hunger is endemic, even in developed countries. Put bluntly, the balance of power between rich and poor, property owner and labourer, seems not to have changed.

But it has. Over the last century the struggles of workers and the poor have yielded global, regional and national human rights frameworks and laws that nominally protect the poor, whether they be labour laws, laws against exploitation of children, or laws against human trafficking. Struggles have also entrenched and deepened acceptance that humans have rights, often protecting these rights in laws, giving them content and meaning that go far beyond the rights outlined in the post-World War 2, Eleanor-Roosevelt inspired, Universal Declaration of Human Rights (UDHR).

Today there are numerous international human rights covenants and treaties, as well as rights entrenched in many (but by no means all) national constitutions. The right to health, for example, appears in one form or another in more than seventy constitutions worldwide. These rights are often the outcome of struggles or campaigns that have highlighted particular areas of abuse of human beings; the Convention on the Rights of People with Disabilities is an example. In a few instances, they are the results of successful organising against multinational companies; the Framework Convention on Tobacco Control is the best example of this. However, none of these frameworks or the rights they recognise are self-enacting. They must be used as a platform for further and future mobilisation.

Although some on the left argue that the South African Constitution was a compromise that entrenched unequal power relations, the TAC took seriously the human rights that are guaranteed in the Constitution's Bill of Rights and campaigned continuously for their enforcement - a demand for the legal enforcement of rights is expressed in every TAC campaign.

The results have been far-reaching:

- There are now 2.4 million people on ARV treatment in South Africa, and there is a Cabinetapproved plan to increase this number to 4 million by 2015 (SANAC, 2013).

- The cost of a standard first-line HIV drug regimen in the public sector dropped from R100 000 per patient per year in the 1990s to less than R1 080 per patient per year today.

- There has been a huge infusion of resources into the public health system to deal with HIV and TB.

- There are new international protections around the right to health, particularly the Doha Declaration.

- Through a series of court judgments there has been an enforcement of rights and a deepening of democracy and clarification of the pro-poor duties of the South African state.

(For a more complete analysis of the TAC's achievements, see Heywood, 2009).

\section{Part III \\ The Challenges that Face the TAC: Could the International Trade Union Movement Play a Role?}

In the twenty-first century hundreds of millions of people now occupy the social borderlands of permanent unemployment and poverty. They do so because of a technological revolution that has brought about profound and irreversible changes to the labour market. These people are the 
families, relatives and friends of what remains of the organised working class. It would be a great step forward if the labour movement were to do more to reach out to and work with social movements, inspiring them with their discipline, history and traditions, and assisting with resources.

Up to now this article has looked at the successes of the TAC and how they were aided by learning from and working with the trade unions. But it is equally important to analyse the difficulties, failures and challenges. I argue that the trade union movement needs to examine the difficulty of sustaining organisations like the TAC, particularly if social movements of the poor are considered essential to narrowing inequality and demanding accountability from governments and private power.

\section{Who funds movements of the poor?}

Perhaps the greatest challenge now facing the TAC is how it and similar social movements are funded. When the TAC was started it had no money, staff or office. For the first two years it depended on the resources of other organisations, particularly the AIDS Law Project and AIDS Consortium (the two NGOs that could be said to have birthed the TAC). However, the success of the TAC's campaigns and the rise of a highly effective global AIDS activist movement catalysed a rising tide of global governmental concern about AIDS (Heywood, 2014). For most of the 2000s countering AIDS was considered a global priority. Multilateral organisations, particularly the United Nations AIDS programme (known as UNAIDS), were forced to respond to civil society and formally recognise that protecting human rights and citizen participation in decision making about health were key to the control of HIV.

This was accompanied by a huge rush of financial resources towards HIV/AIDS, including to support activism driven by civil society. A huge injection of funding was made into HIV and health, and a new paradigm seemed to develop which saw larger and larger amounts of bilateral funding going outside of government and into NGOs, faith-based organisations and so on. This was something from which the TAC benefitted.

South Africa was the epicentre of the global epidemic and therefore AIDS denialism, rather than being a harmless aberration, became a matter of global political concern, drawing senior global leaders such as Bill Clinton into the fray. With hindsight it can be seen that because the TAC led in the fight against President Mbeki's AIDS denialism, almost opportunistically the TAC received significant funding from a range of bilateral donors.

So, as Figure 2 illustrates, in the space of less than a decade the TAC's budget grew from nothing to over R50 million per annum (approximately US $\$ 5$ million).

Predictably, with the growth in funding came a growth in the size and cost of TAC's infrastructure - and thus a growing dependence on its donors. This is a vicious circle if ever there was one! In a few years the TAC grew to have a national office, as well as large offices in six provinces. Its staff grew to over one hundred. At one point its treatment literacy programme had several hundred practitioners and trainers, each receiving a monthly stipend. Dependence on donors deepened with every new office or employee. At the height of its popularity with donors, the TAC was setting future traps for itself.

In this way the TAC made itself vulnerable to the vicissitudes of developed country aid policies. Many of these donors' commitments to AIDS would prove to be short-term. 


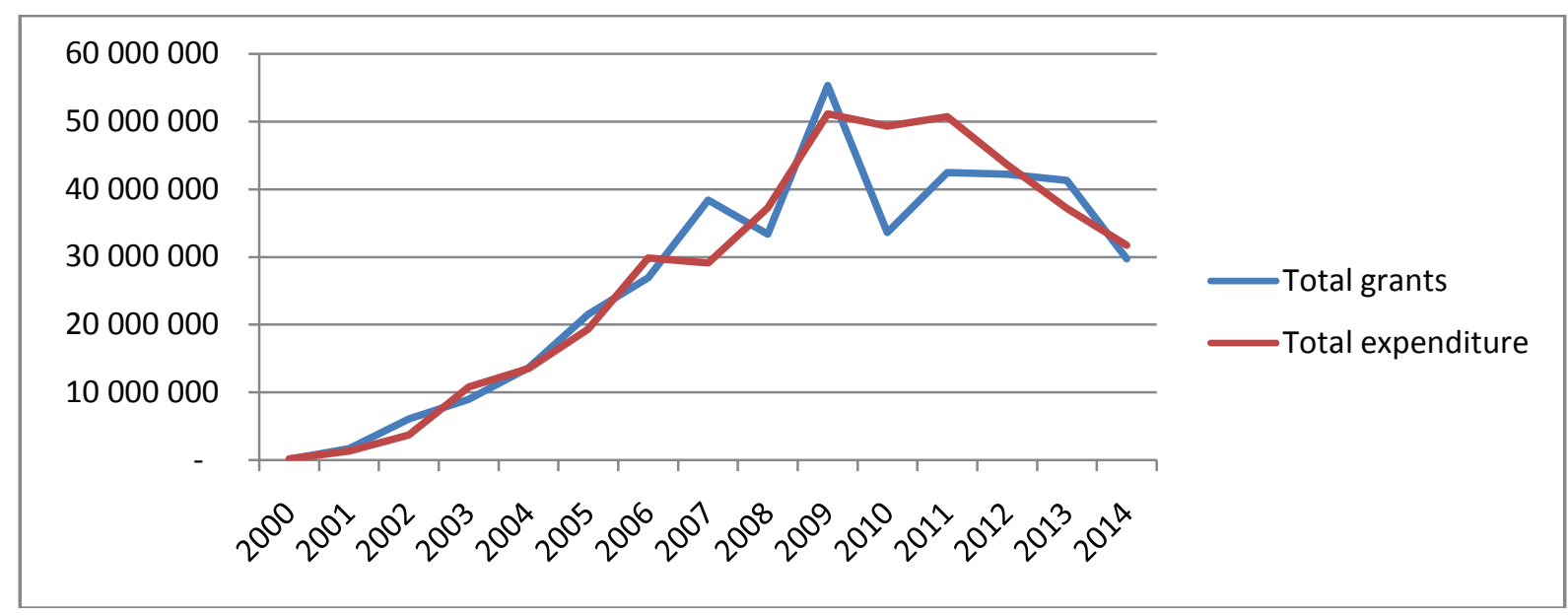

Source $T A C$ resource mobilisation department.

Figure 2: TAC Income and Expenditure, 2000-2014

Neither did the governments who gave the TAC funding, including several European countries, understand or share the TAC's radical transformative agenda. Even though few donors tried to directly influence the TAC's political agenda, organisations like the Global Fund Against AIDS, TB and Malaria (GFATM) imposed complex reporting standards, evaluations and schedules that demanded ever more sophisticated and expensive management systems and highly qualified personnel. The result was that the TAC's leaders began to spend more time maintaining donors and donor systems than organising communities on the ground. This, too, took its toll as local activists felt directionless, unsupported and alienated from the national leadership.

The point at which AIDS denialism can be said to have been completely defeated came with the appointment of Dr Aaron Motsoaledi as South Africa's Health Minister in May 2009. Then, linked to its rapprochement with government, the TAC got gently nudged into service delivery, including organising condom distribution campaigns and providing treatment literacy in clinics in the absence of any government-led health programmes to teach people to understand their health generally and HIV infection in particular. In 2008, after an 'evaluation' initiated by the Swedish International Development Agency (SIDA), persuasive but mistaken arguments were made by the TAC's leaders (including myself) to limit the organisation's activities to six 'model districts' where there would be concentrated activity and advocacy to ensure that all parts of the NSP were implemented at district level. Activists in branches that were not part of the model districts were effectively pruned from the TAC.

The motivation for this may have been correct in part. The TAC's model and path were unsustainable; it would never be able to support or manage limitless growth of its branches from its national office. However, the new model was also unsuitable. Between 2008 and 2012 the TAC became less visible and more cumbersome, its leadership forced to concentrate on managing its structures, raising and reporting on funding rather than campaigns, and thus becoming more and more detached from its constituency.

In 2014 the TAC faced a serious funding crisis that forced it to begin to change its approach to fundraising. It began to down-scale its budget, and appealed for funds directly to individuals and organisations that supported social justice. This is work in progress. But in the words of Zackie 
Achmat, the TAC's founder, 'TAC's financial problems could be solved in a day if the wealthy trade union investment companies came to the party. It is scandalous beyond belief that the trade unions don't fund social movements like TAC and contribute to the social economy. Many of their members would not be alive if it were not for TAC' (Dasnois, 2014).

\section{Creating active and organised citizens among the (disorganised) poor}

The membership of a social movement such as the TAC differs from that of the trade unions. It is far more socially and economically unstable. The TAC's members come mostly from among the swollen ranks of the permanently unemployed, particularly women and young people. Such people face continual social and economic challenges that can disrupt the smooth organisation of campaigns as well as organisational stability. They also often lack even basic organising skills. They are not like factory or office workers whose days gain some order and discipline by virtue of their employment. Neither does this 'underclass' have any income, other than that which comes from government grants.

In the early days of the TAC, the movement was partly inspired and built on self-interest. Many of its members were people living with HIV. The threat of death from AIDS was constantly present in the minds of many TAC activists who saw other TAC leaders and friends die of AIDS. Joining the TAC was a way of trying to save your own life.

However, after winning the battle for treatment in 2004,and as the TAC grew and obtained significant funding, new organisational challenges presented themselves. Voluntarism and activism were undermined when the TAC began to expand its paid staff and created stipends for certain categories of organisers. In an environment of mass unemployment and poverty, joining the TAC came to been seen by some as a way of obtaining meagre resources and employment. This has caused competition and division in branches as well as alienation between TAC leaders and TAC members, and between the TAC national office and its structures in the provinces.

In the face of these organisational and financial challenges, in 2012 the TAC's leading bodies its Secretariat (elected national office bearers) and National Council (national office bearers plus provincial and sectoral leaders) - began a new process of self-reflection. An effort was made to understand and admit the organisation's errors, to rediscover its founding values and to debate what it means to be an activist. The aim was to try to steer the organisation back to voluntary, community-based activism that aims to inspire and provide leadership to a social movement of poor people for HIV and TB treatment and health generally. This process has continued. In 2013 and 2014, the TAC decided to do away with its model districts, to re-launch vibrant campaigns and to undertake a number of organisational innovations, including establishing an independent Board of Directors, which has improved its governance, oversight and accountability. After once more gaining significant media attention for its campaigns against corruption in two of South Africa's provinces, as well as for highlighting the deepening problems of the health system and how they impact on HIV treatment, there is widespread recognition that the TAC is back!

\section{Conclusion: Is a Shared Agenda between Trade Unions and Social Movements Possible?}

This article has tried to show how, in twenty-first century struggles for socio-economic improvement and equality, social movements and trade unions have a great deal to gain from joint campaigns. In my view the joint campaign I have described between COSATU and the TAC in the fight over affordable medicines (the PMA campaign) demonstrated the latent power that exists 
between organised labour and social justice activists. The PMA case revealed to the unions the power that can be gained by using the courts and legal process for a new form of political trial - but one that puts not individuals but the system on trial (be it capital or a corrupt state). It also illustrates the gains that can be had from linking poor people's demands to the established international human rights framework.

Unfortunately, the PMA campaign was exceptional. I am not aware that such an alliance has been repeated in South Africa or in other parts of the world. Yet it is possible and potent on a range of widening inequalities such as in basic education, sanitation or access to sufficient food.

In 2015 AIDS and the widening inequality in access to health care services remains an issue of huge importance for the trade union movement, and one where new alliances are both possible and necessary. But this, too, requires introspection and a willingness to look critically at strategies and tactics for fighting inequality. For example, most of the focus in this article has been on the strengths the trade union movement brought to the TAC. But there were and are significant shortcomings as well.

For example, it could be argued that trade union leaders chose to embrace the easy side of AIDS: challenging government proposals for making AIDS a notifiable disease, demanding political leadership, criticising employer discrimination, supporting calls for access to treatment. This was all necessary, but it was not enough. Equally, if not more important, should have been the training of shop stewards and the rank and file of the trade union movement to understand the science and treatment of HIV so that they would be equipped to be activists both in the workplace and the communities where they lived. Similarly, the predominantly male-led trade union movement was unable (or perhaps unwilling) to tackle the deeper social and behavioural inequalities in which its own leaders and members were implicated.

In particular there are the festering sores of sexism, gender inequality and abuses of positions of power and leadership in the unions in return for sexual relations with women. In South Africa women have formal equality under the law, but this has not stopped ongoing sexual and social inequality. Tackling gender inequality, and overcoming it, is one form of HIV prevention. However, while there has been great lip service by male leaders to this it has often not carried through to their own behaviour and attitudes to women, including women comrades, who remain vulnerable to sexual abuse and the imbalance of power.

Sixteen years after it was launched the TAC remains an important campaign in South Africa, with more than five thousand activists organised across the country. It is one of the few postapartheid social movements that has survived and outlived the initial campaigns and purpose for which they were launched. It owes some of this to the trade union movement. It also offers lessons to other social movements, particularly of the value of seeking an alliance with organised labour. But this must be accompanied by an understanding that building such an alliance means building trust which takes time.

In recent years the TAC has undergone a successful leadership transition with many of the activists who joined the TAC as rank-and-file activists now occupying leadership positions. Although the environment around HIV has changed profoundly, most obviously because treatment action has brought treatment access, the TAC remains a thorn in the side of government and pharmaceutical companies. Its campaigns have shifted focus, particularly to monitoring and improving the public health system, but it continues to be necessary to keep up pressure to put more people on treatment as well as to prevent reversals in political commitment to tackling HIV. ${ }^{14}$ The TAC has brought about substantive equality in access to medicines, but its agenda is far from finished.

Global Labour Journal, 2015, 6(3), Page 331 


\section{NOTES}

${ }^{1} \mathrm{HIV}$ is a virus largely transmitted through three means: predominantly unprotected sexual intercourse between men and women as well as between men and men; from an HIV-positive pregnant woman to her child during and after birth; and through risk behaviours, particularly intravenous drug use. Acquired Immune Deficiency Syndrome (AIDS) refers to the life-threatening illnesses that develop after HIV has weakened the immune system so that it can no longer protect a person from illness. In developing countries tuberculosis (TB) is the disease that kills most people with AIDS. Today, anti-retroviral treatment prevents most people with HIV from developing AIDS. It has dramatically reduced HIV-related illness and death across the globe. Because of the stigma associated with HIV, activists refer to people infected with HIV as 'people living with HIV/AIDS' rather than using the stigmatising terms like 'AIDS victims' or 'AIDS sufferers'.

${ }^{2}$ See: http://www.health-e.org.za/2012/08/02/progress-in-reducing-mother-to-child-transmission/

${ }^{3}$ In late 2014, over 60 of the world's leading scientists signed a letter acknowledging the TAC and making a call to donors to fund its continuing campaigns. See: http://www.tac.org.za Lnews/scientists'-researchers'-appeal-global-donors. For a cinematic history of the TAC, Taking HAART, see: http://youtu.be/eGwvv0z7--Y

${ }^{4}$ Many of these cases were taken up by the AIDS Law Project (ALP). The fight against unfair discrimination provided the first links between the trade union movement and the NGO movement that developed after apartheid. These relationships were established before the TAC was formed in 1998 (Moyle, 2015).

${ }^{5}$ This problem was compounded by poor statistics, the fact that very few deaths were reported as being caused by HIV and government's refusal to admit to the rapid rise in mortality.

${ }^{6}$ For a cinematic history of the activist movement in the United States, watch How to Survive a Plague, 2012.

${ }^{7}$ As a result of the campaign there was a closer examination of TRIPS by governments of developing countries, apparently making them bolder in asserting national sovereignty and the duty of states to protect and advance human rights against intellectual property rights. In addition multilateral agencies such as the United Nations Joint Programme on AIDS (UNAIDS) published guidelines based on human rights, making recommendations to states that public health should not be undermined by patents. Indeed, such was the pressure in the wake of the PMA case that in November 2001 the fourth Ministerial conference of the WTO in Doha formulated a 'Ministerial Declaration on the TRIPS Agreement and Public Health', making it clear that governments have the right to override intellectual property rights in the interests of public health. For background to and analysis of the Doha Declaration see Loff and Heywood (2002b).

${ }^{8}$ The campaign was supported by organisations such as Oxfam, Action Aid and Médecins Sans Frontières. It led to resolutions in the European Parliament on rights of access to medicines, and even to a statement attacking the pharmaceutical companies by author John Le Carré, who in the same year had published a novel, The Constant Gardner, set around the exploitative practices of pharmaceutical companies in Kenya.

${ }^{9}$ Fuller accounts of AIDS denialism, and how it was confronted by the TAC, can be found in Heywood (2004), Nattrass (2007) and Geffen (2010).

${ }^{10}$ According to the report of this Congress, there were over 300 delegates from labour, representing each of South Africa's three trade union federations.

${ }^{11}$ These publications are available at http://www.tac.org.za/publications. 
${ }^{12}$ The classic example of the weaving together of protest and law was the TAC's campaign around preventing mother-to-child transmission of HIV, described in Heywood (2003). See also Heywood (2005a).

13 The docket and charge sheet developed in this campaign can be found at: http://www.tac.org.za/newsletter/2003/ns20 03 2003.htm\#Docket.

${ }^{14}$ See: Making a Mark: TAC's Achievements in 2013 at www.tac.org.za. On 12-13 September 2013, the TAC organised demonstrations in seven provinces to protest against stock-outs of essential medicines, including ARVs, and to draw attention to the virtual collapse of health systems in the Eastern Cape province. These demonstrations received wide publicity and led to the government immediately announcing a task team to investigate the Eastern Cape. The TAC also helped catalyse a policy process that led the government to publish a new draft policy on Intellectual Property that would permit and encourage South Africa to take advantage of TRIPS flexibilities to control and reduce the price of essential medicines.

\section{REFERENCES}

Chiumia, S. (2015) Are 60\% of SA’s Sex Workers HIV Positive? Mail \& Guardian, 28 January 2015. Available online at http://mg.co.za/article/2015-01-28-are-60-of-sas-sex-workers-hiv-positive; accessed January 2015.

Competition Commission (2014) 15 years of competition enforcement: A people's account. Available online at: http://compcom.co.za.www15.cpt4.host-h.net/wpcontent/uploads/2014/09/15-Years-of-Competition-Enforcement.pdf.

Dasnois, A. (2014) Unions should Rescue TAC, says Achmat. Ground Up, 10 December 2014. Available online at http://groundup.org.za/article/unions-should-rescue-tac-saysachmat 2518; accessed March 2015.

Dorrington, R. and Bradshaw, D. (2005) AIDS-related Morality in South Africa: The Evolving Epidemic. In HIV/AIDS in South Africa, $2^{\text {nd }}$ edition, edited by Salim Karim and Quarraisha Karim. Cambridge: Cambridge University Press.

Geffen, N. (2010) Debunking Delusions, the Inside Story of the Treatment Action Campaign. Johannesburg: Jacana.

Gouws, E. and Karim, Q.A. (2005) HIV Infection in South Africa: The Evolving Epidemic. In HIV/AIDS in South Africa, $2^{\text {nd }}$ edition, edited by Salim Karim and Quarraisha Karim. Cambridge: Cambridge University Press.

Heywood, M. (2002a) Debunking 'Conglomo-talk': A Case Study of the amicus curiaeas an Instrument for Advocacy, Investigation and Mobilisation. Law, Democracy and Development, 5(2): 133-62.

Heywood, M. (2002b) Drug Access, Patents and Global Health: 'Chaffed and Waxed Sufficient'. Third World Quarterly, 23(2): 217-33.

Heywood, M. (2003) Preventing Mother to Child HIV Transmission in South Africa: Background, Strategies and Outcomes of the TAC Case against the Minister of Health. South African Journal on Human Rights, 19(2): 278-316.

Heywood, M. (2004) The Price of Denial. Development Update, 5(3): 93-123.

Heywood, M. (2005a) Shaping, Making and Breaking the Law in TAC's Campaign for a National 
Treatment Plan. In Democratising Development: The Politics of Socio-economic Rights in South Africa, edited by P. Jones and K. Stokke. Nijhoff Law Specials. Leiden: Boston.

Heywood, M. (2005b) The Achilles Heel - The Impact of HIV/AIDS on Democracy in South Africa. In HIV/AIDS in South Africa, first edition, edited by S. Karim and Q. Karim. Cambridge: Cambridge University Press.

Heywood, M. (2009) South Africa's Treatment Action Campaign: Combining Law and Social Mobilisation in the Struggle for Health. Journal of Human Rights Practice, 1(1): 14-36.

Heywood, M. (2010) Picking up the Pieces: The End of AIDS Denialism and its Aftermath.. HIV/AIDS in South Africa, second edition, edited by S. Karim and Q. Karim. Cambridge: Cambridge University Press.

Heywood, M. (2013a) The Legacy of Pius Langa - Advancing the Rule of Poor Law. The Daily Maverick, 29 July 2013. Available online at http://www.dailymaverick.co.za/opinionista/201307-29-the-legacy-of-pius-langa-advancing-the-rule-of-poor-law/\#.UfYReqDkbwx.

Heywood, M. (2013b) The Poverty of Power and the Powers of Poverty. The Daily Maverick, 26 July 2013. Available online at http://www.dailymaverick.co.za/opinionista/2013-07-26-the-povertyof-power-and-the-powers-of-poverty/\#.UfYRiKDkbww.

Heywood, M. (2014) The Unravelling of the Human Rights Response to HIV and AIDS and why it Happened: An Activists' Perspective. Aids Today. Available online at http://www.aidsalliance.org/assets/000/001/014/ESSAY1_MarkHeywood original.pdf?1412 $\underline{944701 .}$.

Heywood, M. (2015) Seize Power! The Role of the Constitution in Unifying Social Justice Struggles in South Africa. In Capitalism's Crises: Class Struggles in South Africa and the World, edited by Vishwas Satgar. Johannesburg: Wits University Press.

Independent Online (2001) Drug Firms Holding SA to Ransom. Independent Online, 15 January 2001. Available online at http://www.iol.co.za/news/south-africa/drug-firms-holding-sa-health-toransom-1.56502?ot=inmsa.ArticlePrintPageLayout.ot.

Jochelson, K., Mothibeli, M, and Leger, J-P.(1991) Human Immuno Deficiency Virus and Migrant Labour in South Africa. International Journal of Health Services, 21: 157-73.

Loff, B. and Heywood, M. (2002) Patents on Drugs: Manufacturing Scarcity or Advancing Health? American Journal of Law, Ethics and Medicine, 20(4): 608-21.

Malan, M. (2014) After Drastic Drop SA Life Expectancy Rises. Mail \& Guardian, 19 December 2014.Available online at: http://mg.co.za/article/2014-12-19-sa-life-expectancy-drops.

Motsoaledi, A. (2014) Budget Speech of the Minister of Health, July 2014. Available online at http://www.health.gov.za/docs/media/MinisterHealthBudgetVoteSpeech24July2014.pdf.

Moyle, D. (2015) The History of the AIDS Law Project, Speaking Truth to Power. Johannesburg: Jacana.

Naidoo, J. (2010) Fighting for Justice: A Lifetime of Political and Social Activism. Johannesburg: Picador Africa.

Nattrass, N. (2007) Mortal Combat: AIDS Denialism and the Struggle for Antiretrovirals in South Africa. Pietermaritzburg: University of KwaZulu-Natal Press. 
Section 27 and Treatment Action Campaign (TAC) (Undated) 10 years of ARVS in South Africa. Available online at: www.nspreview.org.

Slovo, J. (1995) Slovo: The Unfinished Autobiography. Johannesburg: Ravan.

South African National AIDS Council (SANAC). 2013. The National Strategic Plan 2012-2016 in a Nutshell. Available online at http://www.sanac.org.za/about-us/nsp/the-national-strategic-plan.

Thomas, S. (2008) Cosatu warns of Riots over Food Price Hikes. Mail \& Guardian, 14 April 2008. Available online at http://mg.co.za/article/2008-04-14-cosatu-warns-of-riots-over-food-pricehikes.

Thompson, C. (1989) Trade Unions using the Law. In Law and Social Practice in South Africa, edited by Hugh Corder. Johannesburg: Juta.

Vavi, Z. (2014) Open Letter to the SACP. 17 December 2014. Available online at http:/ / www.numsa.org.za/article/response-comrade-jeremy-cronin-open-letter-leadersmembers-south-african-communist-party-sacp-zwelinzima-vavi-general-secretary-congresssouth-african-trade.

\section{BIOGRAPHICAL NOTE}

MARK HEYWOOD is the director of Section 27, a public-interest law firm campaigning for the right to health in South Africa. he was one of the founders of the TAC. He continues to work for social justice and to try to build people's movements that hold both government and private power accountable and advance human rights. [Email: heywood@section27.org.za] 